\title{
BETWEEN JUGGLING, STUNTS, AND ANTICS: THE MEANING OF WORK FOR CIRCUS ARTISTS
}

\author{
ANGELA MARIA DE L. MEDEIROS ${ }^{1}$ \\ (iD) https://orcid.org/0000-0001-6065-2025 \\ TEREZA CRISTINA B. DE LIMA ${ }^{1}$ \\ (iD) https://orcid.org/0000-0002-6594-4921 \\ LUIS EDUARDO B. PAIVA ${ }^{1}$ \\ (iD) https://orcid.org/0000-0002-5036-6823 \\ RAFAELA DE A. ARAÚJO \\ (iD) https://orcid.org/0000-0002-1828-0683
}

To cite this paper: Medeiros, A. M. L., Lima, T. C. B., Paiva, L. E. B., \& Araújo, R. A. (2018). Between juggling, stunts, and antics: The meaning of work for circus artists. Revista de Administração Mackenzie, 19(spe). doi:10.1590/1678-6971/eRAMD180061

Submission: Apr. 24, 2018. Acceptance: July 16, 2018.

1 Universidade Federal do Ceará (UFC), Fortaleza, CE, Brazil.

\section{(cc) BY}




\section{ABSTRACT}

Purpose: This study aimed to investigate the meanings of the work of circus artists in three dimensions, individual, organizational, and social, following the adaptation to the model of Morin (2001) proposed by Oliveira, Piccinini, Fontoura, and Schweig (2004) and Morin, Tonelli, and Pliopas (2007).

Originality/value: The article stands out because it deals with a category of artists that is losing space within society, being increasingly marginalized. Given this, it becomes relevant to understand the meaning of an activity that is in decline.

Design/methodology/approach: This is a descriptive and exploratory study of a qualitative nature, in which primary data were collected through semi-structured interviews with ten circus artists. For data collection, the content analysis technique was used in Atlas.ti software. Findings: The results point out that there is meaning in work for the circus artists across all dimensions: 1 . In the individual dimension, the pleasure was the predominant factor, since in more than one moment, all the interviewees expressed their satisfaction in belonging to the circus; 2 . In the organizational dimension, utility prevailed, since everyone considered contributing and meeting the needs of the circus; 3. In the social dimension, interpersonal relations, demonstrating that even with evidence of prejudice, external relationships can be formed in the circus. The results contribute to the literature that involves studies with circus artists, considering their meanings of work.

\section{KEYWORDS}

Circus artist. Circus. Content analysis. Meaning of work. Work in decline. 


\section{INTRODUCTION}

The contemporary circus has a rich plurality of possibilities of production, socialization, and work for organization, with unique and dynamic characteristics (Miranda \& Bortoleto, 2018). The art of circus is propagated through the body, revealing emotions, dialogues, and tensions, and presenting a ritual, repetitive, and sometimes a dangerous process, in which there is the possibility of failure, with a performance being considered a failure when it is not completed satisfactorily (Duprat \& Bortoleto, 2016).

Considered a declining cultural activity, the presence of circus presentations in large Brazilian cities is increasingly rare, given the lack of investment and support for the "circus"; and in this context, many artists are motivated and are resisting this problem. Also, there are several social projects that are trying to reverse the current picture, such as the circus school. In an attempt to fill the financial gap in cultural activities, in 1991 the Rouanet Law was promulgated (Brasil, 1991), which created the National Support Program for Culture (PRONAC), with the objective of supporting and directing resources for investments in cultural projects. However, although the circus is related to cultural and artistic activity, there are restrictions in the revision of funding in this area, is destined for few.

This research is justified because there has been little work on circus activities, especially in Brazil, just as the meaning of work is also little explored. There have been recent advances with the research of Morin (2001), whose database was made public by the Meaning of Work International Research Team (MOW) of the 1980s, and subsequently by Oliveira et al. (2004), Brun and Monteiro (2010), Bendassolli, Borges-Andrade, Alves, and Torres (2015), Boas and Morin (2016), and Rodrigues, Barrichello, and Morin (2016). Bendassolli and Borges-Andrade (2015) have confirmed the paradoxical effect of the dynamics of artistic works, in which uncertainty seems to have a motivational effect on artists, which highlights the importance of investigating artists' senses of work, for example, of circuses.

It is pertinent to understand what drives individuals to work, their experiences, and the environment to understand the values and ethics of the group to which they belong, and what forms the meanings of their work (Sharabi, 2017). This is why understanding the meanings of work, which go beyond the economic dimension, becomes so relevant (Borchardt \& Bianco, 2016). Work has gained a new meaning, since individuals seek social recognition for their personal fulfillment (Silva \& Cappelle, 2015), 
mainly through the recognition of the spectator (Bendassolli \& Borges-Andrade, 2015).

Given the above, after searching the major portals of periodicals, such as Spell, Scielo, and Scopus, it was evident that there is a gap in research on the meanings of work of the circus artists; in Brazil, these artists are often marginalized and forgotten. Based on this context, the question that arises is: "What are the meanings of work for circus performers?"

The general objective of this research is to investigate the meanings of work of circus artists. To achieve this, the following specific objectives were outlined: 1 . To identify whether circus work makes sense or not from the perspective of the individual dimension, based on the perspective of circus artists; 2 . To evaluate the role of the organizational dimension in the work of circus artists; 3 . To understand the importance of the social dimension in the work of circus artists.

This research broadens the understanding of the work developed by circus artists, as well as helping in the development of public policies that can facilitate the breaking down of prejudices, improvements in working conditions, and higher valuations for these professionals. As Girelli, Dal Magro, and Werner (2017) emphasize, circus activity is, above all, the way of life of individuals. This study seeks to overcome the gap in the literature on research related to the senses of the work of circus artists, understanding how artists relate to the work environment.

The remainder of this paper is structured as follows. Section 2 deals with work and its origins. Section 3, then, contextualizes circus activity and the circus, showing the difficulties faced by the artists. Section 4 describes the methodological procedures for carrying out the research. In section 5 , the results obtained from the data processing are presented. Finally, in section 6 , the final considerations are discussed, with contributions and reflections for future research.

\section{WORK AND THE MEANING OF WORK}

Work is seen as a way of transforming nature, building something of value for the individual and the organization (Oliveira, Piccinini, Fontoura, \& Schweig, 2004). To be useful, work must be used for some purpose, bringing to those who carry it out identification and meaning (Boas \& Morin, 2016). When one tries to understand work in its innumerable consequences for cultures, and different historical and social moments, it is common to use 
the expression "meaning of work" (Bendassolli \& Tateo, 2018; Brun \& Monteiro, 2010).

Several studies have been carried out to understand the meaning of work (Antal, Debucquet, \& Frémeaux, 2017; Araújo \& Sachuk, 2007; Bendassolli \& Tateo, 2018; Boas \& Morin, 2016; Tolfo \& Piccinini, 2007), which show that unlike other types of resources, individuals have management and control over work, and require participation, satisfaction, and rewards. For this reason, human resource departments perform basic functions, among them, improving the meaning of work with commitment (May, Gilson, \& Harter, 2004), enhancing workers' quality of life (Bernal, 2010; Elangovan, Pinder, \& Mclean, 2010), and the motivational and organizational climate (Rodrigues, Barrichello, Irigaray, Soares, \& Morin, 2017). In this regard, it is important to understand how individuals feel when they perform their tasks, even if at first these do not seem to make sense or motivate the workers.

Work has a considerable influence on workers' motivation (Rodrigues et al., 2017), on their satisfaction (Wrzesniewski, Mccauley, Rozin, \& Schwartz, 1997), and their productivity (Boas \& Morin, 2016; Morin, 2001; Mourão \& Borges-Andrade, 2001), representing a relevant value (Boas \& Morin, 2016; Morin, 2001; Mourão \& Borges-Andrade, 2001) related to the values that a person holds concerning the role that works plays in the personal and social context (Boas \& Morin, 2016; Silva \& Cappelle, 2015).

According to Tolfo and Piccinini (2007), in the view of the MOW group, at the individual level the meaning of work can be defined as the social representation of the task performed by the individual, at the collective level by the feeling of belonging to a united class that carries out common work, and at the social level by the feeling of accomplishing work that contributes to society (Spinelli-De-Sá, Lemos, \& Cavazotte, 2017). The adaptation made by Oliveira et al. (2004) to the classification used by Morin (2001) highlights the meaning of work in the individual, organizational, and social dimensions.

In the individual dimension, work is identified with the person's ethical values, is pleasurable, allows personal appreciation and satisfaction, and enables development and growth (Antal et al., 2017; Morin, Tonelli, \& Pliopas, 2007; Oliveira et al., 2004). In this dimension, work that has no meaning goes against personal values, not allowing growth or recognition for the person (Morin et al., 2007; Oliveira et al., 2004).

The organizational dimension concerns aspects related to usefulness, the organization itself, and interpersonal relations at work (Antal et al., 2017; Oliveira et al., 2004; Tolfo \& Piccinini, 2007). Rosso, Dekas, and 
Wrzesniewski (2010) and Duffy, Autin, and Bott (2015) argue that as employees identify themselves with their work groups, these provide a positive meaning, and satisfaction is related to adjustments in the work environment that lead to a meaning perceived by the worker. Work that has no meaning is seen as unproductive, which leads to loss of time, and personal and professional dissatisfaction (Antal et al., 2017; Oliveira et al., 2004; Tolfo \& Piccinini, 2007).

In the social area, the person must be able to contribute and to be useful to others and society. Thus, work adds value to the person and the society (Antal et al., 2018; Oliveira et al., 2004; Silva \& Capelle, 2017). The absence of meaning is seen when work does not offer benefits to society (Oliveira et al., 2004; Silva \& Cappelle, 2017).

Given this contextualization of work and the meaning of work, the following section deals with the circus and the circus artist, a symbolic profession in labor relations currently (Concolatto, Rodrigues, \& Oltramari, 2017) showing the circus artist in the Brazilian context.

\section{THE CIRCUS AND CIRCUS ACTIVITY}

The traditional circus is an institution with a set of rules and social norms of its own; over time and space, these reaffirm its communal unity, but there are also emerging trends, incorporating circus activity into other artistic contexts, such as theater, dance, and music, related to the contemporary urban cultural mode (Bezerra \& Barros, 2016). Studying the culture, they produce to continue building their territory is the same as understanding the actions and notions that constitute their daily life (Aguiar \& Carrieri, 2016; Bezerra \& Barros, 2016; Ilkiu, 2011).

Given the importance of itinerant activity, in 1978 the National Congress, expressing concern for itinerant activity, promulgated Law 6.533, of May 24, which regulates the professions of artists and technicians in entertainment shows, ensuring in Article 29 the right of vacancy and transfer to public schools in primary and secondary education for the children of these professionals (Brasil, 1978). The circus artist is a cultural worker, as related to culture, according to Law ${ }^{\circ} 6.533 / 78$ (Brasil, 1978). Law No. 6.533 of 1978 , which regulates the work developed by the employed artist, considers as such "the professional who interprets or performs works of any cultural nature, for the purpose of exposure or dissemination through media of mass or in places where public entertainment programs are held" (Brasil, 1978), including circus establishments. 
From Oliveira's (2012) perspective, circus performers can perform their activities independently or as employees. The latter is the case when the performer is subject to the directive power of an employer, able to determine the function, time, and place of the provision of services. Oliveira (2012) also affirms that it is possible to establish the existence of an employment relationship if the artist receives weekly payment and housing, with the obligation to undertake exhibitions in facilities and at hours previously determined by the contractor. As long as the artist does not assume the risk of the business and the artist's activity constituted an attraction, the employment bond is confirmed; however, the circus is made up of families working for their own benefit, often representing the sole livelihood of the family.

In light of the discussion, considering the meaning of work and circus artists, the following section sets out the methodological procedures that led to the results of this research.

\section{METHODOLOGICAL PROCEDURES}

This is a qualitative, descriptive, and exploratory study (Sampieri, Collado, \& Lucio, 2006), based on the model proposed by Oliveira et al. (2004) and Morin et al. (2007), which verifies the meaning of work for the individual, considering also the employer organization (circus) and society.

Data collection was performed through the application of semi-structured interviews. First, questions were asked that sought to verify whether or not the artists understood the meanings of the activities performed; then, the interviews explored their perceptions for each of the analyzed dimensions. All the interviews were recorded, with the participation of the researchers, who were placed as non-participant observers (Godoi, Bandeira-de-Mello, \& Silva, 2006). Data collection was carried out from March 1 to 19, 2017.

The universe of this research was made up of artists from the Puerto Rico Circus (Circo Porto Rico), a medium-sized venture from the Rio Grande do Sul, founded on May 11, 2001, which performs more than 350 shows a year and about 60 shows per season. This circus was awarded the Picadeiro trophy of the Ministry of Culture, and the Piolim and Arte Circense trophies granted by the Government of the State of São Paulo. The interviews were undertaken during the circus's stay in the city of Fortaleza-Ceará (Brazil). This circus was chosen at random because of the willingness of the artists to 
participate in this research. The sample comprised ten circus artists as saturation was reached in the interviewee with this number.

For the analytic instrument, based on Oliveira et al. (2004) and Morin et al. (2007), the categories of analysis were the individual, organizational, and social dimensions of the meanings of work. In the model used, one registration unit excludes the other, i.e.; if the respondent stated that an aspect was meaningful, it was not possible simultaneously for there to be no meaning in that context unit (Figure 4.1).

\section{(Figure 4.1)}

\section{CATEGORIES, CONTEXT, AND RECORD UNITS: MEANINGFUL AND NOT MEANINGFUL WORK}

\begin{tabular}{|c|c|c|c|}
\hline $\begin{array}{l}\text { Analysis } \\
\text { Category }\end{array}$ & $\begin{array}{l}\text { Context } \\
\text { Unit }\end{array}$ & $\begin{array}{l}\text { Registry Unit } \\
\text { Meaningful }\end{array}$ & $\begin{array}{l}\text { Registry Unit } \\
\text { Not Meaningful }\end{array}$ \\
\hline \multirow{11}{*}{$\begin{array}{l}\text { Individual } \\
\text { Dimension }\end{array}$} & \multirow{2}{*}{ Coherence } & Relatedness & Lack of relatedness \\
\hline & & Importance & No importance \\
\hline & \multirow{2}{*}{ Alienation } & Clear & Not clear \\
\hline & & Knows the work objectives & Does not know the work objectives \\
\hline & \multirow{2}{*}{ Valorization } & Valorization & Devaluation \\
\hline & & Acknowledgment & No acknowledgment \\
\hline & Pleasure & Like the work & Does not like the work \\
\hline & \multirow{2}{*}{ Development } & Professional Growth & No professional growth \\
\hline & & Personal development & No personal development \\
\hline & \multirow{2}{*}{$\begin{array}{l}\text { Survival and } \\
\text { independence }\end{array}$} & Meets basic needs & Does not meet basic needs \\
\hline & & Financial feedback & No financial feedback \\
\hline \multirow{6}{*}{$\begin{array}{l}\text { Organizational } \\
\text { Dimension }\end{array}$} & \multirow{2}{*}{ Usefulness } & Contributes to society & Does not contribute to society \\
\hline & & Work meets expectations & Work does not meet expectations \\
\hline & \multirow{4}{*}{$\begin{array}{l}\text { Work } \\
\text { organization }\end{array}$} & Autonomy & Does not have autonomy \\
\hline & & Diversified & Undiversified \\
\hline & & Challenging & Unchallenging \\
\hline & & New ideas or practices & No new ideas or practices \\
\hline
\end{tabular}




\section{(Figure 4.1 (conclusion)) \\ CATEGORIES, CONTEXT, AND RECORD UNITS: MEANINGFUL AND NOT MEANINGFUL WORK}

\begin{tabular}{|c|c|c|c|}
\hline $\begin{array}{l}\text { Analysis } \\
\text { Category }\end{array}$ & $\begin{array}{l}\text { Context } \\
\text { Unit }\end{array}$ & $\begin{array}{l}\text { Registry Unit } \\
\text { Meaningful }\end{array}$ & $\begin{array}{l}\text { Registry Unit } \\
\text { Not Meaningful }\end{array}$ \\
\hline \multirow{2}{*}{$\begin{array}{l}\text { Organizational } \\
\text { Dimension }\end{array}$} & \multirow{2}{*}{$\begin{array}{l}\text { Interpersonal } \\
\text { relationship }\end{array}$} & $\begin{array}{l}\text { Favorable working } \\
\text { environment }\end{array}$ & Unfavorable working environment \\
\hline & & $\begin{array}{l}\text { Acceptance in the work } \\
\text { environment }\end{array}$ & $\begin{array}{l}\text { Lack of acceptance in the work } \\
\text { environment }\end{array}$ \\
\hline \multirow{5}{*}{$\begin{array}{l}\text { Social } \\
\text { Dimension }\end{array}$} & Usefulness & Contributes to society & No contribution to society \\
\hline & \multirow{2}{*}{ Valorization } & Valued by society & Unvalued by society \\
\hline & & Recognition by society & No recognition by society \\
\hline & \multirow{2}{*}{$\begin{array}{l}\text { Interpersonal } \\
\text { relationship }\end{array}$} & $\begin{array}{l}\text { Favorable social } \\
\text { environment }\end{array}$ & Unfavorable social environment \\
\hline & & Acceptance of work & Prejudice by society \\
\hline
\end{tabular}

Source: Adapted from Oliveira et al. (2004) and Morin et al. (2007).

The interviews generated about 120 minutes of audio requiring transcription for later analysis. Before conducting the interviews, we talked to the person in charge of the circus, explaining the objectives of the work, and marking the day and hour of the interviews so as not to obstruct the daily activities of the artists. For the transcription of the interviews, the software Express Dictate v. 5.95 was used.

In the treatment of the data, the content analysis method (Bardin, 2011) was used, understood as a set of research techniques, the objective of which is to seek the meaning or meanings of a document, allowing tabulation, coding, and interpretation in a structured and sequential manner. For the data analysis, the software Atlas.ti (version 8) was adopted.

\section{ANALYSIS AND DISCUSSION OF RESULTS}

For the analysis and discussion of the results, the profile of the circus artists is first presented, and then the dimensions of the meanings of work are analyzed, according to the segmentation of the specific objectives of this research. 


\subsection{Profile of respondents}

The sample comprised ten people, eight male (M) and two female (F). Most had school-age children accompanying the circus (Figure 5.1.1).

\begin{tabular}{|c|c|c|c|c|c|c|c|c|}
\hline Interviewee & Sex & $\begin{array}{c}\text { Age } \\
\text { (years) }\end{array}$ & Education & $\begin{array}{l}\text { From a } \\
\text { circus } \\
\text { family }\end{array}$ & $\begin{array}{c}\text { Have } \\
\text { children }\end{array}$ & $\begin{array}{l}\text { Accompany } \\
\text { the circus }\end{array}$ & Activity & $\begin{array}{l}\text { Circus } \\
\text { time } \\
\text { (years) }\end{array}$ \\
\hline I1 & M & 34 & $\begin{array}{l}\text { Incomplete } \\
\text { elementary } \\
\text { school }\end{array}$ & No & Yes & Yes & $\begin{array}{l}\text { Globe of death } \\
\text { and flying } \\
\text { trapeze }\end{array}$ & 9 \\
\hline 12 & M & 34 & $\begin{array}{l}\text { Incomplete } \\
\text { elementary } \\
\text { school }\end{array}$ & Yes & Yes & Yes & $\begin{array}{l}\text { Trapeze artist, } \\
\text { death globe, } \\
\text { acrobatic } \\
\text { trampoline } \\
\text { (trampoline), } \\
\text { Chinese mast } \\
\text { and others }\end{array}$ & 34 \\
\hline 13 & M & 17 & $\begin{array}{l}\text { Complete } \\
\text { high school }\end{array}$ & Yes & No & - & Juggler & 17 \\
\hline 14 & M & 15 & $\begin{array}{l}\text { Incomplete } \\
\text { elementary } \\
\text { school }\end{array}$ & Yes & No & - & $\begin{array}{l}\text { Trapeze artist, } \\
\text { clown, and } \\
\text { rehearsing the } \\
\text { globe of death }\end{array}$ & 2 \\
\hline 15 & F & 31 & $\begin{array}{l}\text { Complete } \\
\text { high school }\end{array}$ & No & Yes & Yes & $\begin{array}{l}\text { Acrobatic } \\
\text { tissue }\end{array}$ & 9 \\
\hline 16 & M & 43 & $\begin{array}{l}\text { Incomplete } \\
\text { elementary } \\
\text { school }\end{array}$ & Yes & Yes & No & $\begin{array}{l}\text { Equilibrist, } \\
\text { mounting } \\
\text { engineer, } \\
\text { clown, and } \\
\text { scene master }\end{array}$ & 43 \\
\hline 17 & M & 40 & $\begin{array}{l}\text { Incomplete } \\
\text { elementary } \\
\text { school }\end{array}$ & Yes & Yes & Yes & $\begin{array}{l}\text { Unicycle and } \\
\text { carrier }\end{array}$ & 40 \\
\hline 18 & M & 28 & $\begin{array}{l}\text { Incomplete } \\
\text { high school }\end{array}$ & Yes & Yes & Yes & $\begin{array}{l}\text { Clown and } \\
\text { marketing }\end{array}$ & 28 \\
\hline
\end{tabular}


(Figure 5.1 .1 (conclusion))

PROFILE OF RESPONDENTS

\begin{tabular}{ccccccccc}
\hline Interviewee & Sex & $\begin{array}{c}\text { Age } \\
\text { (years) }\end{array}$ & Education & $\begin{array}{c}\text { Froma } \\
\text { circus } \\
\text { family }\end{array}$ & $\begin{array}{c}\text { Have } \\
\text { children }\end{array}$ & $\begin{array}{c}\text { Accompany } \\
\text { the circus }\end{array}$ & Activity & $\begin{array}{c}\text { Circus } \\
\text { time } \\
\text { (years) }\end{array}$ \\
\hline 19 & M & 33 & $\begin{array}{l}\text { Complete } \\
\text { high school }\end{array}$ & No & Yes & No & $\begin{array}{c}\text { Spiderman } \\
\text { and marketing }\end{array}$ & 4.5 \\
\hline 110 & F & 23 & $\begin{array}{l}\text { Incomplete } \\
\text { elementary } \\
\text { school }\end{array}$ & No & Yes & Yes & Lira Fabric No. & 19 \\
\hline
\end{tabular}

Source: Elaborated by the authors.

The respondents have been given identifiers from I1 to I10 to maintain their anonymity. The average length of time spent in circus activities is 20 years and six months. However, there is great breadth here, from the shortest duration of 2 years to the longest of 43 years. The average age is 29.8 years, the youngest being 15 years old (circus performers start early in the profession) and the oldest 43 years old.

\subsection{Dimensions of the meaning of work}

The analysis and discussion of the results are presented for each dimension—individual, organizational, and social—in turn, drawing on the meaning of work from the perspective of the circus artists.

\subsubsection{The individual dimension of the meaning of work}

In the individual dimension, the results are evaluated for the following context units: coherence, alienation, valorization, pleasure, development, and survival and independence. This sub-section seeks to address the first specific objective, which is to identify whether the work makes sense or not from the perspective of the individual dimension, based on the views of the circus artists. The results are represented for each of the context units (Figure 5.2.1.1). 


\section{(Figure 5.2.1.1)}

\section{INDIVIDUAL DIMENSION OF THE MEANING OF WORK}

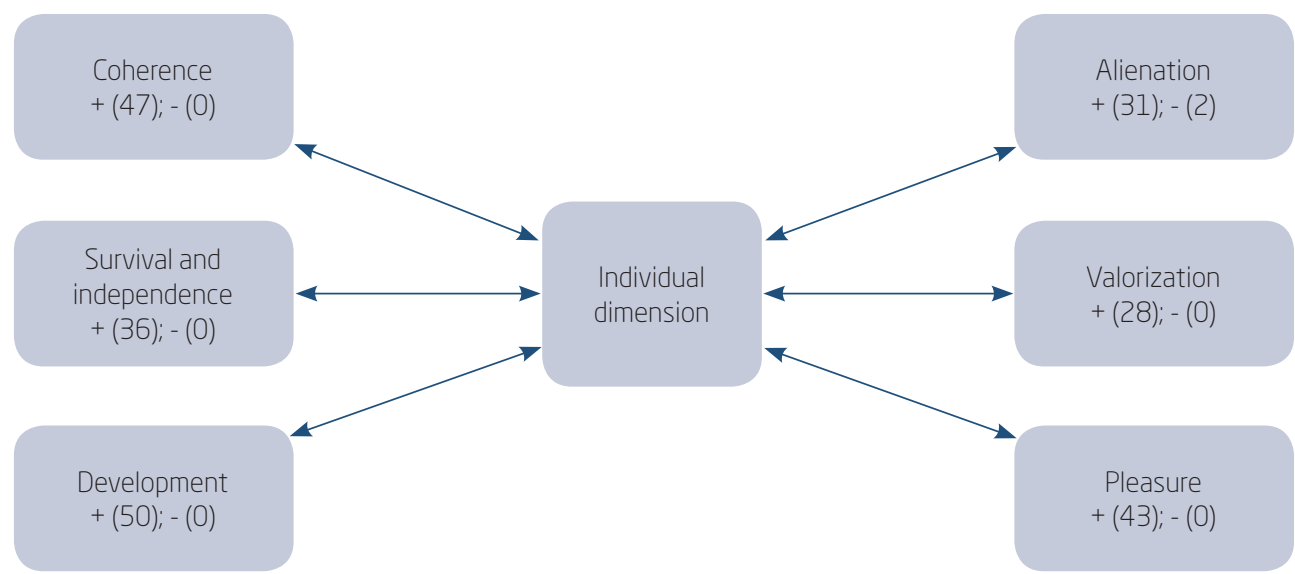

Source: Elaborated by the authors

In the "coherence" context unit, 47 quotations were found. The interviewees reported identifying with their work and considered it important, as we can observe from I2: "Certainly (I identify myself). [...] I adore (what I do) because my life has always been this. I was born in this world and grew up watching everyone working, and we enjoy and learn." Although it is an activity that goes from generation to generation, and thus the circus artist may not have a real notion of the coherence of the work performed, the result of this component is in harmony with Morin (2001), who states that the work and its process helps individual to discover and to form their identities. Tolfo and Piccinini (2007) also emphasize that the meaning of work allows the construction of the personal and social identity of the individual through the tasks performed in the course of work.

In the "alienation" context unit, there were 31 quotations. These showed that the interviewees had the knowledge and perceived the clarity of the objectives of the work. However, there were two mentions of a lack of clarity or lack of knowledge in this regard. For instance, I4 stated "(I present it) because I have learned ... I grasped it, and I go to the end," but when asked if he knew why he presents his number and about the usefulness of his activity, it was possible to perceive that there was no greater reflection on the activity that he performs. In contrast, all other participants had clarity and knowledge of the objectives of the work, totaling 33 occurrences related to alienation. Morin (2001) and Boas and Morin (2016) argue that it is 
necessary for the worker to understand the purpose of the work so that it makes sense, as do most of the circus artists investigated.

In the view of the participants, the "valorization" unit represented 28 quotations, with $100 \%$ corresponding to the recognition and valorization of the work, indicating performance satisfaction. In the case of artistic activity, about this unit, it could be perceived that the activities have a sense-oriented toward values, favoring the pleasure in accomplishing such work. As pointed out by I8:

I feel valued in this circus, and in all where this happens. The team likes my work. [...] Through the social networks and the team when the show ends, they come to hug me, hit the photo, and say that they liked the show, that they liked the clown, and that's where people are happier.

Therefore, it can be concluded that the recognition of artists values what they know how to do, which according to Antal et al. (2017) relates to "valorization."

There were consistent and frequent references to the "pleasure" unit. None of the interviewees showed that they did not like the work, and their passion for the activity was verified in several interviews, totaling 43 positive mentions. The enthusiasm felt during the interviews reflected the pleasure that the interviewees demonstrated in their work, confirming Morin's (2001) and Boas and Morin's (2016) point that satisfaction can be felt when performing tasks that make sense for the work, and it is necessary for there to be pleasure in work to maintain health (Tolfo \& Piccinini, 2007).

In the unit "survival and independence," Morin (2001) and Oliveira et al. (2004) emphasize that the financial element is paramount in ensuring survival, and they conclude that if workers have sufficient money to live comfortably, they will continue to work as it is a source of livelihood and a means of relating to others, integrating them into a group or society. There were 36 references to attention to basic needs and financial returns, none of which were contradictory, as highlighted by I8:

I left (the circus), but I was in need, and in the circus people earn well. In the city, the minimum wage is only received at the end of the month, and here people receive their wage weekly [...] With the circus activity, I paid for a truck, paid for my car, I support my family, I paid my son's pension. 
In the "development" unit, 50 passages were identified that confirm growth in both personal and professional settings, as well as the acquisition of new knowledge and skills. The statements verify that the fields of professional growth and personal development are connected, in line with Tolfo and Piccinini (2007) and Antal et al. (2017), who consider work has meaning when it enables learning, development, recognition, and valorization of the activities that the individual performs.

Only the "alienation" context unit showed negative perceptions, totaling less than $1 \%$. Thus, circus activity has meaning for the interviewees in the individual dimension of their work, which makes sense and can be identified with the moral values of the individual, and this can enable the development and growth of the circus artist.

\subsubsection{The organizational dimension of the meaning of work}

This dimension seeks to meet the second specific objective, which is to evaluate the role of the organizational dimension in the work of circus artists. The results are evaluated for the following context units: usefulness, work organization, and interpersonal relations (Figure 5.2.2.1).

(Figure 5.2.2.1)

ORGANIZATIONAL DIMENSION OF WORK

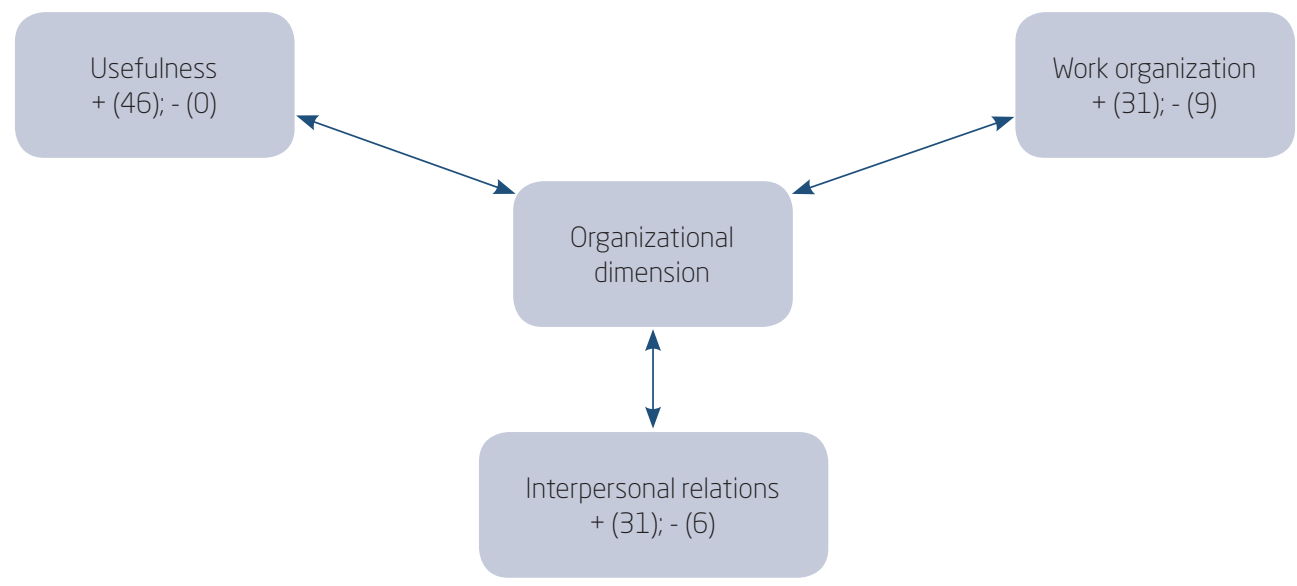

Source: Elaborated by the authors.

In the "usefulness" unit, of the 46 positive mentions, 25 concerned the interviewees' consideration of their work as contributing to the circus, and the 21 interviewees' belief that their work met the expectations of the circus. 
For example, highlighting the meaningfulness of the work, I8 remarked "Besides (the owner of the circus considers my work useful), he values me a lot, thank God [...]. I can do all the tasks and without him asking me to do it." Andrade, Tolfo, and Dellagnelo (2012) confirm that the meaning of work is determined by utility, self-fulfillment, satisfaction, a sense of development, and personal and professional evolution, as well as freedom and autonomy in performing tasks.

The identification of the meaning of work in the "work organization" context unit can be verified through the 39 affirmations among the interviewees regarding autonomy, diversified new ideas or practices, and the challenging nature of the work. Work that makes sense allows the workers to have autonomy, be able to exercise their creativity and think, showing that work in the circus makes sense. The definition of meaningless work is when the task does not motivate the worker. It is important to note that there were nine negative mentions about the artists' work organization.

Regarding diversified work, those who considered their work routine (7.5\% of quotations) confirmed that they learn and improve their performance every day because of repetition. Those who considered their work diversified $(17.5 \%)$ ensure that each day is a new presentation. Moreover, $25 \%$ of the quotations reveal that there is autonomy in the presentation, and there were no instances in the "no autonomy" unit. Regarding the suggestion of ideas or new practices, $17.5 \%$ of the quotations affirm that they can make proposals, while only $7.5 \%$ reported not having this opportunity/freedom of suggestion. According to I6:

It is great (the routine), because I am learning more and more, and I am getting better and better. [...] I have (the freedom to suggest some new idea or practice when I am doing my number). I say I'm going to make such a position—go, do, please, fine. [...] (My job) is challenging, there are few that do it.

Regarding "interpersonal relations," there were four passages in which this aspect was considered unfavorable in the view of the participants, corresponding to $11 \%$ of the quotations. In two quotations, this was related to a lack of acceptance in the work environment, corresponding to approximately $5 \%$ of the mentions. The main complaint about the circus concerned the interactions between the artists themselves and the difficulty of making friends outside the work environment, indicating that circus performers are close to each other, and there is a strengthening of interpersonal relations only in the work environment. 
In line with Oliveira et al. (2004) and Rosso et al. (2010), there were several positive quotations regarding meaningful work, namely the "favorable work environment" and "acceptance at work." This is exemplified by I1, who stated "It is quiet (the work environment is good), thank God. There are some who are bored, but people swallow it up." In addition, I2 noted "It is (the work environment is good). Sometimes, there are some discussions that are ordinary, but most are okay."

The organizational dimension of the work includes aspects related to utility, work organization, and interpersonal relations in the work environment. For Tolfo and Piccinini (2007), for a job to make meaning in the organizational dimension, it must achieve results, have value for the company or the group, and be useful. Otherwise, the work will be unproductive, generating wastage of time, and failing to have any sense. The circus activity has meaning for the interviewees in the organizational dimension; although there were some negative mentions, these were far fewer than the positive statements. Thus, it is possible to infer that circus artists perceive meaning in their work for the organizational dimension.

\subsubsection{The social dimension of the meaning of work}

In this dimension, we seek to meet the third specific objective, which is to understand the importance of the social dimension for the work of circus artists. The results are evaluated for the following context units: usefulness, valorization, and interpersonal relations (Figure 5.2.3.1).

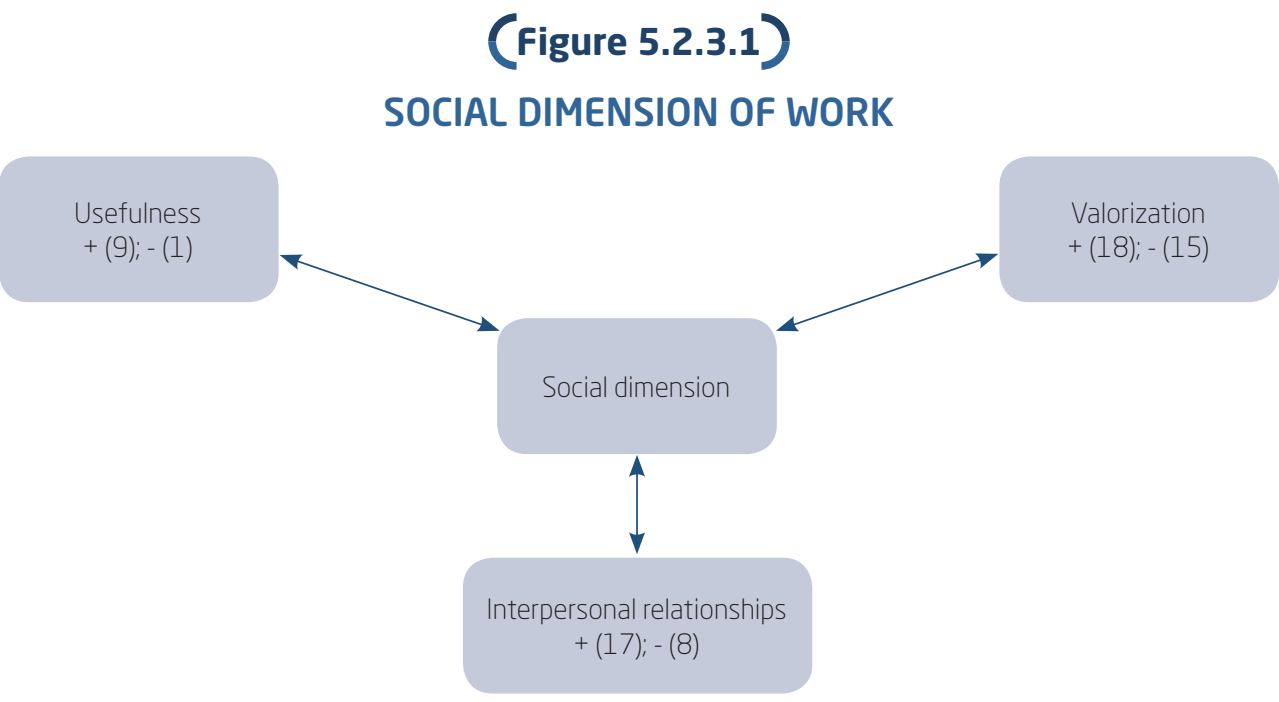


The social dimension of work presents $65 \%$ positive references and $35 \%$ negative, showing that the work makes sense from circus artists. The "usefulness" context unit seeks to discover whether the work contributes to society. Only one of the interviewees (I4) did not perceive the work as contributing to the development of society, stating "[...] we do shows in school too, I understand if I say, let's go, we'll do it, we'll have a birthday." In contrast, the other interviewees believed that their work contributes to society. As mentioned by I8:

... It is (my work contributes to society), it is through clowning that we help to explain more the heads of the children, of society. There are people who have prejudice about race, sexual choice, and we explain that each person has a choice and each person makes life what he/she wants.

Based on the above, it is possible to corroborate Morin et al.'s (2007) findings, since some interviewees reported that work makes sense when it contributes to society, transcending, in this case, individual and organizational issues.

Although sharing the same nomenclature as in the individual dimension, the "valorization" context unit within the scope of the social dimension takes a different approach, seeking to identify value and recognition by society. In this regard, there were 33 quotations, with $54 \%$ indicating value and recognition by society. Regarding the positive quotations, I1 stands out: "Some, yes, not all (of society values us). [We perceive this] because there are places and people that say "these people of the circus are equal to gypsies, not quiet,' and discriminate a lot against the circus some people, not all."

Despite some positive quotations expressing a lack of prejudice and discrimination, there were also emphatically negative quotations. Among these, I6 stands out: "They could give more value, more recognition to the circus, they think that we, with permission for the word, are marginal, but we are citizens... we pay our taxes, and they do not see it, Hail Mary." As Morin (2002) comments, work should allow the union between activities and social sanctions, contributing to the construction of social identity and protecting the personal dignity, rather than contributing to prejudice in society.

Concerning "interpersonal relations," there are references to some kind of discrimination within society. This is highlighted by the testimony of I5:

Often the people we meet in the city ask if we are from the circus and think that we have nowhere to sleep, nowhere to bathe, as if the circus played it, but they never come to me to say something positive. 
Despite remarks such as those of I5 and I6, the study reaffirms Silva and Cappelle's (2017) point that even with the prejudice experienced by artists, they continue to identify meaning in the activities they perform. The context unit "interpersonal relations" in the social dimension presents a greater emphasis on discrimination, described as continued prevalence of prejudice against the circus and circus artists.

\subsection{Summary of key results}

The main results found in this study are presented in Figure 5.3.1, with the number of positive and negative references, linked to the main theoretical bases.

\section{(Figure 5.3.1)}

SUMMARY OF MAIN RESULTS

\begin{tabular}{|c|c|c|c|c|c|}
\hline \multirow{2}{*}{$\begin{array}{l}\text { Analysis } \\
\text { Category }\end{array}$} & \multirow{2}{*}{$\begin{array}{c}\text { Context } \\
\text { Unit }\end{array}$} & \multicolumn{2}{|c|}{ Results } & \multirow{2}{*}{ Comment } & \multirow{2}{*}{ Theoretical Basis } \\
\hline & & + & - & & \\
\hline \multirow{5}{*}{$\begin{array}{l}\text { Individual } \\
\text { Dimension }\end{array}$} & Coherence & 47 & 0 & $\begin{array}{l}\text { The interviewees unanimously } \\
\text { identify with their work and consider } \\
\text { it important, identifying their work as } \\
\text { consistent. }\end{array}$ & $\begin{array}{l}\text { Morin (2001); } \\
\text { Tolfo and Piccinni } \\
\text { (2007) }\end{array}$ \\
\hline & Alienation & 31 & 2 & $\begin{array}{l}\text { The interviewees have the } \\
\text { knowledge and perceive the clarity of } \\
\text { the objectives of the work; with only } \\
\text { two negative mentions there is a low } \\
\text { level of alienation. }\end{array}$ & Morin (2001) \\
\hline & Valorization & 28 & 0 & $\begin{array}{l}\text { All the interviewees affirmed their } \\
\text { work is recognized and valorized, } \\
\text { indicating satisfaction in the } \\
\text { performance of the work. }\end{array}$ & Antal et al. (2017) \\
\hline & Pleasure & 43 & 0 & $\begin{array}{l}\text { No-one indicated not liking their } \\
\text { work; rather, passion for exercising } \\
\text { their activities stands out. }\end{array}$ & $\begin{array}{l}\text { Morin (2001); Tolfo } \\
\text { and Piccinini } \\
\text { (2007) }\end{array}$ \\
\hline & Development & 50 & 0 & $\begin{array}{l}\text { There is the possibility of growth, } \\
\text { both in the personal and professional } \\
\text { fields, as well as the acquisition of } \\
\text { new knowledge and the development } \\
\text { of new skills. }\end{array}$ & $\begin{array}{l}\text { Antal et al. (2017); } \\
\text { Tolfo and Piccinini } \\
\text { (2007) }\end{array}$ \\
\hline
\end{tabular}




\section{(Figure 5.3.1 (conclusion)) \\ SUMMARY OF MAIN RESULTS}

\begin{tabular}{|c|c|c|c|c|c|}
\hline \multirow{2}{*}{$\begin{array}{l}\text { Analysis } \\
\text { Category }\end{array}$} & \multirow{2}{*}{$\begin{array}{l}\text { Context } \\
\text { Unit }\end{array}$} & \multicolumn{2}{|c|}{ Results } & \multirow{2}{*}{ Comment } & \multirow{2}{*}{ Theoretical Basis } \\
\hline & & + & - & & \\
\hline $\begin{array}{l}\text { Individual } \\
\text { Dimension }\end{array}$ & $\begin{array}{l}\text { Survival and } \\
\text { independence }\end{array}$ & 36 & 0 & $\begin{array}{l}\text { The artists confirmed the possibility } \\
\text { of financial independence. }\end{array}$ & $\begin{array}{l}\text { Morin (2001); } \\
\text { Oliveira et al. (2004) }\end{array}$ \\
\hline \multirow{3}{*}{$\begin{array}{l}\text { Organizational } \\
\text { Dimension }\end{array}$} & Usefulness & 46 & 0 & $\begin{array}{l}\text { The artists consider their work } \\
\text { contributory, and meeting the } \\
\text { expectations of the circus, } \\
\text { highlighting meaningful work. }\end{array}$ & $\begin{array}{l}\text { Andrade et al. } \\
\text { (2012); Antal et al. } \\
\text { (2017); Tolfo and } \\
\text { Piccinini (2007) }\end{array}$ \\
\hline & $\begin{array}{l}\text { Work } \\
\text { organization }\end{array}$ & 31 & 9 & $\begin{array}{l}\text { There were mentions of activities } \\
\text { being routine and little diversified } \\
\text { due to the need to repeat } \\
\text { presentations, but this is seen as a } \\
\text { challenge to be overcome, as each } \\
\text { show presents a risk of failure. Work } \\
\text { is viewed positively. }\end{array}$ & Morin et al. (2007) \\
\hline & $\begin{array}{l}\text { Interpersonal } \\
\text { relations }\end{array}$ & 31 & 6 & $\begin{array}{l}\text { There were only two negative } \\
\text { references regarding acceptance in } \\
\text { the workplace, and four concerning } \\
\text { the lack of a favorable environment. }\end{array}$ & $\begin{array}{l}\text { Antal et al. (2017); } \\
\text { Duffy et al. (2014); } \\
\text { Rosso et al. (2010); } \\
\text { Tolfo and Piccinini } \\
\text { (2007) }\end{array}$ \\
\hline \multirow{3}{*}{$\begin{array}{l}\text { Social } \\
\text { Dimension }\end{array}$} & Usefulness & 9 & 1 & $\begin{array}{l}\text { Only one interviewee did not seem to } \\
\text { see the usefulness of their work to } \\
\text { society. }\end{array}$ & Morin et al. (2007) \\
\hline & Valorization & 18 & 15 & $\begin{array}{l}\text { There were } 15 \text { negative references } \\
\text { to society's perception of the work of } \\
\text { the circus, especially regarding } \\
\text { prejudice and discrimination against } \\
\text { artists. }\end{array}$ & $\begin{array}{l}\text { Morin (2001; } \\
\text { 2004); } \\
\text { Wrzesniewski } \\
\text { et al. (1997) }\end{array}$ \\
\hline & $\begin{array}{l}\text { Interpersonal } \\
\text { relations }\end{array}$ & 17 & 8 & $\begin{array}{l}\text { The social relations artists } \\
\text { maintained were within the work } \\
\text { environment. They once again } \\
\text { highlighted prejudice, and there were } \\
\text { eight mentions of discrimination on } \\
\text { the part of society. }\end{array}$ & $\begin{array}{l}\text { Oliveira et al. } \\
\text { (2004); Silva and } \\
\text { Cappelle (2017) }\end{array}$ \\
\hline
\end{tabular}

Note: + Positive

- Negative

Source: Elaborated by the authors. 
These results provide an overview of the meaning of work for circus performers, showing that in the individual dimension their work offers an opportunity to develop their physical abilities (Antal et al., 2017; Miranda \& Bortoleto, 2018), provides pleasure, and makes the individuals feel valued (Antal et al., 2017; Tolfo \& Piccinini, 2007); however, in terms of organization, the diversity of tasks and interpersonal relations were perceived as negative, especially concerning the difficulty of maintaining relationships in view of the itinerant aspect of the circus (Bezerra \& Barros, 2016); in the social dimension, there were contrasting responses in the valuation aspect, and the prejudice experienced by circus artists became more evident.

This research is relevant in investigating the meaning of work for circus artists, a category of artists losing space within society. This is especially significant as circus activities represent the way of life for these people. In general, the findings show that these circus artists perceive the meaning of their work and this is also related to how they perceive the world and insert themselves in society, thus bringing a sense of identity and social inclusion.

\section{FINAL CONSIDERATIONS}

This research had as its general objective investigating the meanings of the work of circus artists. Using the model proposed by Oliveira et al. (2004), based on Morin et al. (2007), three specific objectives were outlined, considering the individual, organizational, and social dimensions of the meaning of work.

From the perspective of the individual dimension, the findings verify that the work has meaning: According to the testimony of the artists, their work in the circus makes them feel fulfilled and satisfied because it promotes development, improvement, survival, and independence, which allows them to develop their personal and social identities, as well as to be pleasurable. In the organizational dimension there is also meaning in work. The interviewees believe that they meet the interests and needs of the circus, considering it mainly a challenging, diversified, and autonomous work. Moreover, in the social dimension, there is a sense in social work in that respondents believe they contribute to society and are valued, in addition to maintaining good interpersonal relationships.

Although there are instances in the data that show perceptions of low appreciation for circus artists, as well as prejudice, discrimination, and even marginalization, there is a discernable positive balance in the valorization. In 
this regard, the interpersonal relations factor presents the highest positive balance. These findings point to the reasons why circus professionals continued to feel motivated to develop their activities, despite the difficulty that circuses face in maintaining presentations in the country. Notwithstanding the artists' understanding of the meaning of their work, with its challenges and potentialities, it is important to focus on the prejudice identified in the social dimension, namely that they are marginalized by society; this meant that there was little difference in the results of the valorization context unit.

This research contributes to practical terms by affording professionals in the circus reality the ability to avoid problems such as increased child prostitution and chemical dependency. In the academic field, the research seeks to broaden the perceptions of artists in a field of activity that is in decline. Specifically, this research provides a greater understanding of the meaning of work in the circus environment, seeking to contribute to a change in the stigmatized view, and thus mitigate the devaluation that the circus and the artists have been suffering.

The results presented here cannot be generalized as the sample in this research may not be representative of artists more widely. In particular, the interviews were performed only with artists from one circus, of medium size, with a good structure and conceptualization in the circus environment. Thus, as a suggestion for future study, this research could be extended to artists from other circuses (located in other cities and countries), and other artists, such as musicians, dancers, and actors, to provide a broader picture of the meaning of the work of artists. Moreover, quantitative research on the meaning of work for circus artists could be carried out.

\section{ENTRE MALABARES, ACROBACIAS E PALHAÇADAS: 0 SENTIDO DO TRABALHO PARA ARTISTAS CIRCENSES}

\section{RESUMO}

Objetivo: Este estudo teve como objetivo investigar os sentidos do trabalho dos artistas circenses, nas três dimensões: individual, organizacional e social, seguindo a adaptação do modelo de Morin (2001), propostas por Oliveira et al. (2004) e Morin, Tonelli e Pliopas (2007).

Originalidade/valor: $\mathrm{O}$ artigo se destaca por tratar de uma categoria de artistas que está perdendo espaço dentro da sociedade, sendo cada vez 
mais marginalizada. Diante disso, torna-se relevante entender qual o sentido de uma atividade que está em declínio.

Design/metodologia/abordagem: Trata-se de um estudo descritivo e exploratório, de natureza qualitativa, em que, por meio de entrevistas semiestruturadas, foram coletados dados primários com dez artistas circenses. Para coleta de dados, utilizou-se a técnica da análise de conteúdo com o uso do software Atlas.ti.

Resultados: Os resultados apontam que há sentido no trabalho para os artistas circenses em todas as dimensões: 1 . Na dimensão individual, o fator que predominou foi o prazer, pois em mais de um momento todos os entrevistados enalteceram sua satisfação em pertencer ao circo; 2 . Na dimensão organizacional, a utilidade predominou, já que todos consideram contribuir e atender às necessidades do circo; e 3. Na dimensão social, as relações interpessoais demonstraram que, mesmo com o preconceito em evidência, é possível relacionamentos externos ao circo. Os resultados contribuem para a literatura que envolve pesquisas com artistas circenses, levando-se em conta os seus sentidos do trabalho.

\section{PALAVRAS-CHAVE}

Artista circense. Circo. Análise de conteúdo. Sentido do trabalho. Trabalho em declínio.

\section{REFERENCES}

Aguiar, A. R. C., \& Carrieri, A. P. (2016). “Água de lona” e "Sangue de serragem" nos discursos de sujeitos circenses. Organizações E Sociedade, 23(77), 247-262. doi:10.1590/1984-9230774

Andrade, S. P. C., Tolfo, S. R., \& Dellagnelo, E. H. L. (2012). Sentidos do trabalho e racionalidades instrumental e substantiva: Interfaces entre a Administração e a Psicologia. Revista de Administração Contemporânea, 16 (2), 200-216. doi:10.1590/S1415-65552012000200003

Antal, A. B., Debucquet, G., \& Frémeaux, S. (2017). Meaningful work and artistic interventions in organizations: Conceptual development and empirical exploration. Journal of Business Research. doi:10.1016/j.jbusres. 2017.10.015 
Araújo, R. R., \& Sachuk, M. I. (2007). Meanings attributed to labor and their implications in contemporary organizations. REGE Revista de Gestão, 14(1), 53-66.

Bardin, L. (2011). Análise de conteúdo. Lisboa, PT: Edições 70.

Bendassolli, P. F., \& Borges-Andrade, J. E. (2015). Meaning, meaningfulness, and tensions in artistic work. Revista Psicologia Organizações e Trabalho, 15(1), 71-81. doi:10.17652/rpot/2015.1.305

Bendassolli, P. F., Borges-Andrade, J. E., Alves, J. S. C., \& Torres, T. D. L. (2015). Meaningful work scale in creative industries: A confirmatory factor analysis. Psico-USF, 20(1), 1-12. doi:10.1590/1413-82712015200101

Bendassolli, P. F., \& Tateo, L. (2018). The meaning of work and cultural psychology: Ideas for new directions. Culture \& Psychology, 24(2), 135-159. doi:10.1177/1354067X17729363

Bernal, A. O. (2010). Psicologia do trabalho em um mundo globalizado: Como enfrentar o assédio psicológico e o estresse no trabalho. Porto Alegre, RS: Artmed.

Bezerra, J. H., \& Barros, J. M. (2016). Participação social no campo da cultura e disputas simbólicas nas políticas culturais para o circo em Fortaleza (CE). Ciências Sociais Unisinos, 52 (1), 27-34. doi:10.4013/csu.2016.52.1.04

Boas, A. A. V., \& Morin, E. M. (2016). Sentido do trabalho e fatores de qualidade de vida no trabalho: a percepção de professores brasileiros e canadenses. Revista Alcance, 23(3), 272-292. doi:10.14210/alcance. v23n3(Jul-Set).p272-292

Borchardt, P., \& Bianco, M. D. F. (2016). Meanings of volunteer work: A study with members of a lutheran institution. Revista de Administração Mackenzie, 17(5), 61-84. doi:http://dx.doi.org/10.1590/1678-69712016/ administracao.v17n5p61-84

Brasil. (1978). Lei n. ${ }^{\circ}$ 6.533, de 24 de maio de 1978. Dispõe sobre a regulamentação das profissões de Artistas e de técnico em Espetáculos de Diversões, e dá outras providências, 1978. Retrieved from http://www.planalto.gov. br/ccivil_03/leis/L6533.htm

Brasil. (1988). Constituição da República Federativa do Brasil. promulgada em 5 de outubro de 1988, atualizada até a Emenda Constitucional n ${ }^{\circ}$ 96, de 06 de junho de 2016, 1988. Retrieved from http://www.planalto.gov.br/ ccivil_03/constituicao/constituicao.htm

Brun, L. G., \& Monteiro, J. K. (2010). O estado da arte do sentido do traba1ho. Psicologia.PT, 1-27. 
Concolatto, C. P., Rodrigues, T. G., \& Oltramari, A. P. (2017). mudanças nas relações de trabalho e o papel simbólico do trabalho na atualidade. Farol-Revista de Estudos Organizacionais e Sociedade, 4(9), 341-390.

Duffy, R. D., Autin, K. L., \& Bott, E. M. (2015). Work volition and job satisfaction: Examining the role of work meaning and person-environment fit. The Career Development Quarterly, 63(2), 126-140. doi:10.1002/ cdq. 12009

Duprat, R. M., \& Bortoleto, M. A. C. (2016). O corpo na formação dos circenses. ILINX-Revista do LUME, 2(8), 1-11.

Elangovan, A. R., Pinder, C. C., \& McLean, M. (2010). Callings and organizational behavior. Journal of Vocational Behavior, 76(3), 428-440. doi:10.1016/j.jvb.2009.10.009

Girelli, S., Dal Magro, M. L. P., \& Werner, L. (2017). Bem-vindos ao espetáculo: Sentidos do trabalho para artistas circenses. Revista de Ciências Humanas, $51(2), 456-476$.

Godoi, C. K., Bandeira-de-Mello, R., \& Silva, A. D. (2006). Pesquisa qualitativa em estudos organizacionais: paradigmas, estratégias e métodos. São Paulo, SP: Saraiva.

Ilkiu, E. C. (2011). Respeitável público, o circo chegou: trajetórias e malabarismos de um espetáculo. Temporalidades, 3(1), 81-103.

May, D. R., Gilson, R. L., \& Harter, L. M. (2004). The psychological conditions of meaningfulness, safety and availability and the engagement of the human spirit at work. Journal of Occupational and Organizational Psychology, 77(1), 11-37. doi:10.1348/096317904322915892

Miranda, R. D. C. F., \& Bortoleto, M. A. C. (2018). O circo na formação inicial em educação física: um relato autoetnográfico. Revista Brasileira de Ciências do Esporte, 40(1), 39-45. doi:10.1016/j.rbce.2018.01.004

MOW (1987). The meaning of working. Academic Press.

Morin, E. M. (2001). Os sentidos do trabalho. Revista de administração de empresas, 41 (3), 8-19. doi:10.1590/S0034-75902001000300002

Morin, E., Tonelli, M. J., \& Pliopas, A. L. V. (2007). O trabalho e seus sentidos. Psicologia \& sociedade, 19(1), 27-56. doi:10.1590/S0102-71822007 000400008

Mourão, L., \& Borges-Andrade, J. E. (2001). Significado do trabalho: caminhos percorridos e sinalização de tendências. Revista de Estudos Organizacionais, 2(2), 59-76. 
Oliveira, S. R., Piccinini, V. C., Fontoura, D. D. S., \& Schweig, C. (2004). Buscando o sentido do trabalho. Anais do Encontro Nacional da Associação Nacional de Pós-Graduação e Pesquisa em Administração, Porto Alegre, RS, Brasil, 28.

Oliveira, V. B. (2012). Artistas circenses: Importância na cultura brasileira e questões jurídicas relevantes. Políticas Culturais em Revista, 4(2), 130-145.

Rodrigues, A. L., Barrichello, A., \& Morin, E. M. (2016). Os sentidos do trabalho para profissionais de enfermagem: Um estudo multimétodos. Revista de Administração de Empresas, 56(2), 192-208. doi:10.1590/S0034759020160206

Rodrigues, A. L., Barrichello, A., Irigaray, H. A. R., Soares, D. R., \& Morin, E. M. (2017). O trabalho e seus sentidos: Um estudo com peritos criminais da Polícia Federal. Revista de Administração Pública, 51 (6), 1058-1084. doi:10.1590/0034-7612159318

Rosso, B. D., Dekas, K. H., \& Wrzesniewski, A. (2010). On the meaning of work: A theoretical integration and review. Research in organizational behavior, 30, 91-127. doi:10.1016/j.riob.2010.09.001

Sampieri, R. H., Collado, C. F., \& Lucio, P. B. (2006). Metodologia de pesquisa. Tradução de Fatima Conceição Murad, Melissa Kassner, Sheila Cara Dystyler Cadeira. Revisão técnica de Ana Gracinda Queluz Garcia, 1-583.

Silva, K. A. T., \& Cappelle, M. C. A. (2015). Sentidos do trabalho apreendidos por meio de fatos marcantes na trajetória de mulheres prostitutas. Revista de Administração Mackenzie, 16(6), 19-47. doi:10.1590/167869712015/administracao.v16n6p19-47

Silva, K. A. T., \& Cappelle, M. C. A. (2017). O trabalho na prostituição de luxo: Análise dos sentidos produzidos por prostitutas em Belo HorizonteMG. Environmental \& Social Management Journal/Revista de Gestão Social e Ambiental, 23-39. doi:10.24857/rgsa.v0i0.1391

Sharabi, M. (2017). The meaning of work dimensions according to organizational status: Does gender matter? Employee Relations, 39(5), 643-659. doi:10.1108/ER-04-2016-0087

Spinelli-De-Sá, J. G., Lemos, A. H. D. C., \& Cavazotte, F. D. S. C. N. (2017). Making a career in a male-dominated field: the meaning of work for women employed in the financial markets. Revista de Administração Mackenzie, 18(4), 109-136. doi:10.1590/1678-69712017/administracao.v18n4p109-136

Tolfo, S. D. R., \& Piccinini, V. C. (2007). Sentidos e significados do trabalho: Explorando conceitos, variáveis e estudos empíricos brasileiros. Psicologia E Sociedade, 19(1), 38-46. doi:10.1590/S0102-71822007000400007 
Wrzesniewski, A., McCauley, C., Rozin, P., \& Schwartz, B. (1997). Jobs, careers, and callings: People's relations to their work. Journal of research in personality, 31 (1), 21-33. doi:10.1006/jrpe.1997.2162

\section{AUTHOR NOTES}

Angela Maria de L. Medeiros, Faculdade de Economia, Administração, Atuária e Contabilidade, Universidade Federal do Ceará (UFC); Tereza Cristina B. de Lima, Faculdade de Economia, Administração, Atuária e Contabilidade, Universidade Federal do Ceará (UFC); Luis Eduardo B. Paiva, Faculdade de Economia, Administração, Atuária e Contabilidade, Universidade Federal do Ceará (UFC); Rafaela de A. Araújo, Faculdade de Economia, Administração, Atuária e Contabilidade, Universidade Federal do Ceará (UFC).

Angela Maria de L. Medeiros is now Researcher at Faculdade de Economia, Administração, Atuária e Contabilidade at Universidade Federal do Ceará (UFC); Tereza Cristina B. de Lima is now Professor at Faculdade de Economia, Administração, Atuária e Contabilidade at Universidade Federal do Ceará (UFC); Luis Eduardo B. Paiva is now Faculdade de Economia, Administração, Atuária e Contabilidade at Universidade Federal do Ceará (UFC); and Rafaela de A. Araújo is now Master's student in administration and controllership at Universidade Federal do Ceará (UFC).

Correspondence concerning this article should be addressed to Luis Eduardo B. Paiva, Avenida da Universidade, 2431, Benfica, Fortaleza, Ceará, Brazil, CEP: 60020-180.

E-mail: edubrandas@gmail.com

\section{EDITORIAL BOARD}

Editor-in-chief

Silvio Popadiuk

Associated Editor

Alcides Barrichello

Technical Support

Vitória Batista Santos Silva

\section{EDITORIAL PRODUCTION}

Publishing Coordination

Irina Migliari

Editorial Trainee

Maria Luiza Vanz

Copy Editor

Irina Migliari

\author{
Language Editor \\ Daniel Leão \\ Layout Designer \\ Emap \\ Graphic Designer \\ Libro
}

